Article

\title{
Silicon-Doped Titanium Dioxide Nanotubes Promoted Bone Formation on Titanium Implants
}

\author{
Xijiang Zhao ${ }^{1,2,+}$, Tao Wang ${ }^{1,+}$, Shi Qian ${ }^{3}$, Xuanyong Liu ${ }^{3, *}$, Junying Sun ${ }^{1, *}$ and Bin $\mathrm{Li}^{1, *}$ \\ 1 Department of Orthopaedics, the First Affiliated Hospital, Orthopaedic Institute, Soochow University, \\ 188 Shizi St, Suzhou 215006, China; zhaoxijiangruilet@aliyun.com (X.Z.); wtfamily@163.com (T.W.) \\ 2 Department of Orthopedics, the Affiliated Hospital of Jiangnan University, 200 Huihe Rd, \\ Wuxi 214062, China \\ 3 State Key Laboratory of High Performance Ceramics and Superfine Microstructures, \\ Chinese Academy of Sciences, 1295 Dingxi Rd, Shanghai 200050, China; qianshi@mail.sic.ac.cn \\ * Correspondence: xyliu@mail.sic.ac.cn (X.L.); sun_junying@hotmail.com (J.S.); binli@suda.edu.cn (B.L.); \\ Tel.: +86-21-5241-2409 (X.L.); +86-512-6778-0101 (J.S.); +86-512-6778-1163 (B.L.) \\ + These authors contributed equally to this work.
}

Academic Editor: John G. Hardy

Received: 15 January 2016; Accepted: 15 February 2016; Published: 26 February 2016

\begin{abstract}
While titanium (Ti) implants have been extensively used in orthopaedic and dental applications, the intrinsic bioinertness of untreated Ti surface usually results in insufficient osseointegration irrespective of the excellent biocompatibility and mechanical properties of it. In this study, we prepared surface modified Ti substrates in which silicon $(\mathrm{Si})$ was doped into the titanium dioxide $\left(\mathrm{TiO}_{2}\right)$ nanotubes on $\mathrm{Ti}$ surface using plasma immersion ion implantation (PIII) technology. Compared to $\mathrm{TiO}_{2}$ nanotubes and $\mathrm{Ti}$ alone, Si-doped $\mathrm{TiO}_{2}$ nanotubes significantly enhanced the expression of genes related to osteogenic differentiation, including Col-I, ALP, Runx2, OCN, and OPN, in mouse pre-osteoblastic MC3T3-E1 cells and deposition of mineral matrix. In vivo, the pull-out mechanical tests after two weeks of implantation in rat femur showed that $\mathrm{Si}$-doped $\mathrm{TiO}_{2}$ nanotubes improved implant fixation strength by $18 \%$ and $54 \%$ compared to $\mathrm{TiO}_{2}-\mathrm{NT}$ and Ti implants, respectively. Together, findings from this study indicate that $\mathrm{Si}$-doped $\mathrm{TiO}_{2}$ nanotubes promoted the osteogenic differentiation of osteoblastic cells and improved bone-Ti integration. Therefore, they may have considerable potential for the bioactive surface modification of Ti implants.
\end{abstract}

Keywords: silicon doping; titanium dioxide nanotubes; titanium; osteogenic differentiation; MC3T3-E1 cells; osseointegration

\section{Introduction}

Taking advantage of their excellent biocompatibility and mechanical properties, titanium (Ti) and its alloys have been extensively used in orthopedic and dental applications these days [1,2]. However, the intrinsic bioinertness of untreated Ti surface usually results in insufficient bone formation and consequent osseointegration, which increases the risk of instability after surgical procedures including total joint replacement such as total hip arthroplasty (THA) or spinal fusion [3,4]. Instability after THA, for example, is a major cause of revision surgeries, contributing to $22.5 \%$ of THA revisions in the United States [5]. Therefore, a number of attempts have been made to improve the bioactivity of Ti surface in order to accelerate biological fixation of implants and reduce the chance of aseptic loosening of them.

In recent years, surface modification of Ti alone and Ti alloys by changing the surface chemistry [6,7], wettability [8], roughness [2,9], surface energy [10], microstructure [11,12] and nanotopography [13,14] 
has been tried to enhance their osseointegrative potential. Introducing anodic titanium dioxide $\left(\mathrm{TiO}_{2}\right)$ nanotubes onto the Ti surface is among one of the approaches. A highly ordered $\mathrm{TiO}_{2}$ nanotube array with the lateral dimension within the sub- $100 \mathrm{~nm}$ region forms on the surface of Ti substrate when it is anodized in fluoride-containing electrolytes $[15,16]$. $\mathrm{TiO}_{2}$ nanotubes have proven effective in promoting bone formation. For example, the growth of osteoblasts was accelerated by as much as $300 \%-400 \%$ when grown on anodic $\mathrm{TiO}_{2}$ nanotubes compared to the osteoblasts grown on unanodized $\mathrm{Ti}$ [17]. Cells grown on $\mathrm{TiO}_{2}$ nanotube surfaces also showed stronger ALP activity and more calcium deposition $[18,19]$.

In addition to surface topography, different elements such as carbon [20], tantalum [21], zinc [22], magnesium [23], and silicon (Si) [24] have been introduced onto Ti surfaces through various surface treatment techniques for improving their osteogenic activity. A relatively less used trace element, $\mathrm{Si}$, has been found to localize at the active sites of calcification in young bone and is therefore suggested to be closely related to calcium at early calcification stage [25]. In general, the introduction of a small amount of Si may markedly affect the adhesion, proliferation, and differentiation of osteoblastic cells and mesenchymal stem cells (MSCs) [26-29]. For example, Botelho et al. found that the expression of osteoblastic marker genes was up-regulated in cells grown on apatite substituted with $0.8 \mathrm{wt} \% \mathrm{Si}$ [27]. In an in vivo study, Camiré et al. discovered $1 \mathrm{wt} \%$ Si-doped $\alpha$-tri-calcium phosphate $(\alpha-\mathrm{TCP})$ showed significantly increased osteoclastic and osteoblastic activities and bone integration compared to pure $\alpha$-TCP [30]. In contrast, Si deficiency may lead to abnormal bone formation [25,31].

Recently, we have found that, compared to pure $\mathrm{TiO}_{2}$, Si-doped $\mathrm{TiO}_{2}$ coatings prepared using cathodic arc deposition [32,33] or micro-arc oxidation [24] favored the activities of osteoblastic cells. In this study, we were interested in examining whether Si doping could further enhance the osteogenic potential of $\mathrm{TiO}_{2}$ nanotubes. To this end, we prepared three groups of Ti-based substrates, i.e., Ti alloy (Ti), $\mathrm{Ti}$ alloy with $\mathrm{TiO}_{2}$ nanotubes at the surface $\left(\mathrm{TiO}_{2}-\mathrm{NTs}\right)$, and Si-doped Ti alloy with $\mathrm{TiO}_{2}$ nanotubes at the surface $\left(\mathrm{Si}-\mathrm{TiO}_{2}-\mathrm{NTs}\right)$. We then compared the activities of MC3T3-E1 cells on them and also determined the in vivo fixation strength of implants made from the above materials through pull-out biomechanical tests.

\section{Results}

\subsection{Preparation of $\mathrm{TiO}_{2}-\mathrm{NTs}$ and $\mathrm{Si}-\mathrm{TiO}_{2}-\mathrm{NT}$ Substrates}

$\mathrm{TiO}_{2}-\mathrm{NTs}$ were prepared via electrochemical anodic oxidation on the surface of Ti substrates. Following that, $\mathrm{Si}-\mathrm{TiO}_{2}-\mathrm{NT}$ substrates were prepared using the $\mathrm{Si}$ plasma immersion ion implantation technique. As shown from SEM imaging (Figure 1), $\mathrm{Si}-\mathrm{TiO}_{2}-\mathrm{NTs}$ had almost identical microstructures as $\mathrm{TiO}_{2}-\mathrm{NTs}$, meaning that $\mathrm{Si}$ doping treatment did not cause apparent change of the surface topography of $\mathrm{TiO}_{2}-\mathrm{NTs}$. The $\mathrm{TiO}_{2}$ nanotubes had an outer diameter of $\sim 70 \mathrm{~nm}$ and inner diameter of $\sim 60 \mathrm{~nm}$. Figure 2 shows the characteristic peaks of $\mathrm{Ti}, \mathrm{O}$ and $\mathrm{C}$ elements in the $\mathrm{X}$-ray photoelectron spectroscopy (XPS) spectra of $\mathrm{TiO}_{2}-\mathrm{NT}$ and $\mathrm{Si}-\mathrm{TiO}_{2}-\mathrm{NT}$ substrates. The characteristic peaks of $\mathrm{Si}$ were only seen on Si-treated substrates, indicating that $\mathrm{Si}$ had been successfully doped into the $\mathrm{TiO}_{2}$ nanotubes. The Si content was estimated to be about $0.51 \mathrm{wt} \%$.
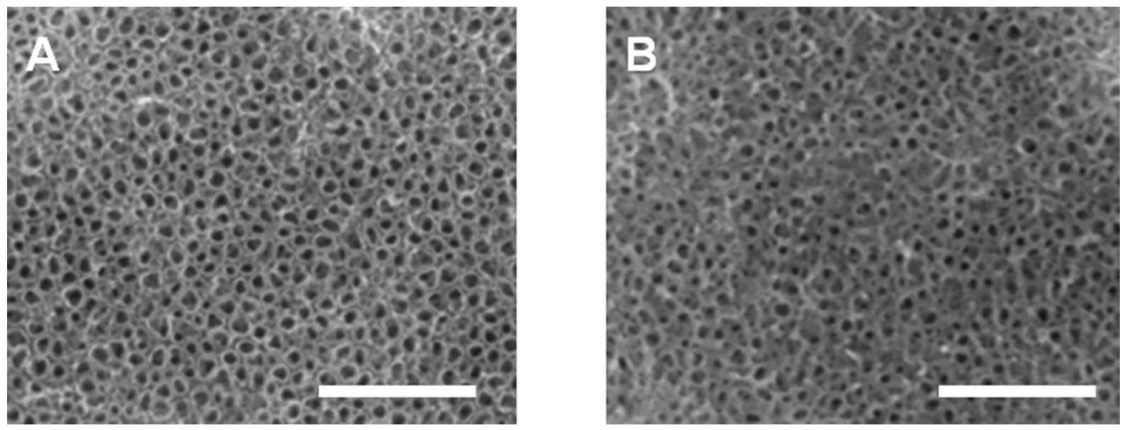

Figure 1. SEM images of $\mathrm{TiO}_{2}-\mathrm{NTs}(\mathbf{A})$ and $\mathrm{Si}-\mathrm{TiO}_{2}-\mathrm{NTs}(\mathbf{B})$ surfaces. Scale bars, $1 \mu \mathrm{m}$. 


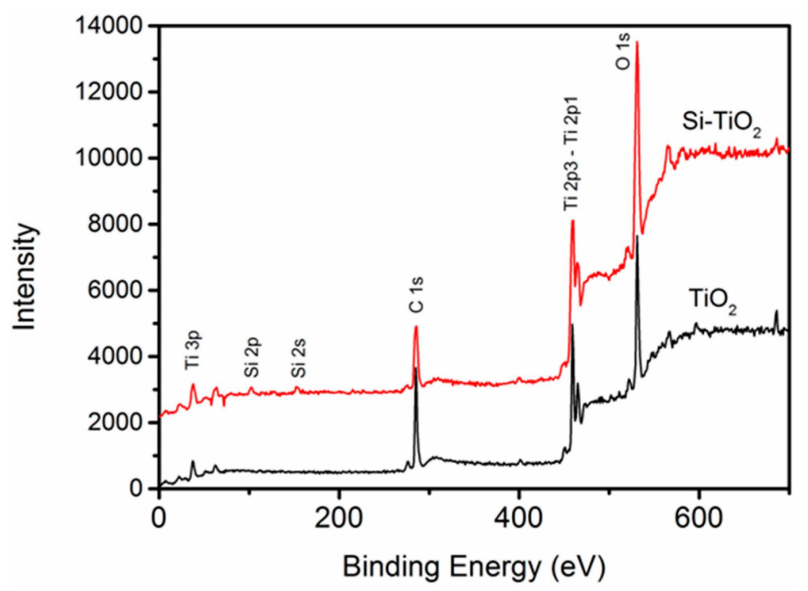

Figure 2. The chemical profiles of $\mathrm{TiO}_{2}-\mathrm{NTs}$ and $\mathrm{Si}-\mathrm{TiO}_{2}-\mathrm{NT}$ surfaces determined using XPS.

\subsection{Cell Adhesion and Proliferation}

Figure 3 shows SEM images of MC3T3-E1 pre-osteoblastic cells after $24 \mathrm{~h}$ of culture on $\mathrm{Ti}, \mathrm{TiO}_{2}-\mathrm{NT}$ and $\mathrm{Si}-\mathrm{TiO}_{2}-\mathrm{NT}$ substrates. As can be clearly seen, the cells showed relatively round morphology when cultured on Ti. However, they exhibited much flattened and irregular morphology on $\mathrm{TiO}_{2}-\mathrm{NT}$ and $\mathrm{Si}-\mathrm{TiO}_{2}-\mathrm{NT}$ substrates. Moreover, extensive filopodial processes were seen on both $\mathrm{TiO}_{2}-\mathrm{NT}$ and $\mathrm{Si}-\mathrm{TiO}_{2}-\mathrm{NT}$ substrates but not on Ti substrates. As shown by the immunofluorescence that revealed the cytoskeletal actin of cells, the cells on Ti remained small and round and seemed to lack microfilaments (Figure 4). The cells became markedly larger on $\mathrm{TiO}_{2}-\mathrm{NT}$ and $\mathrm{Si}-\mathrm{TiO}_{2}-\mathrm{NT}$ substrates. Importantly, the actin filaments seemed to be better developed within MC3T3-E1 cells on $\mathrm{Si}-\mathrm{TiO}_{2}-\mathrm{NT}$ substrates than on $\mathrm{TiO}_{2}-\mathrm{NT}$ substrates.
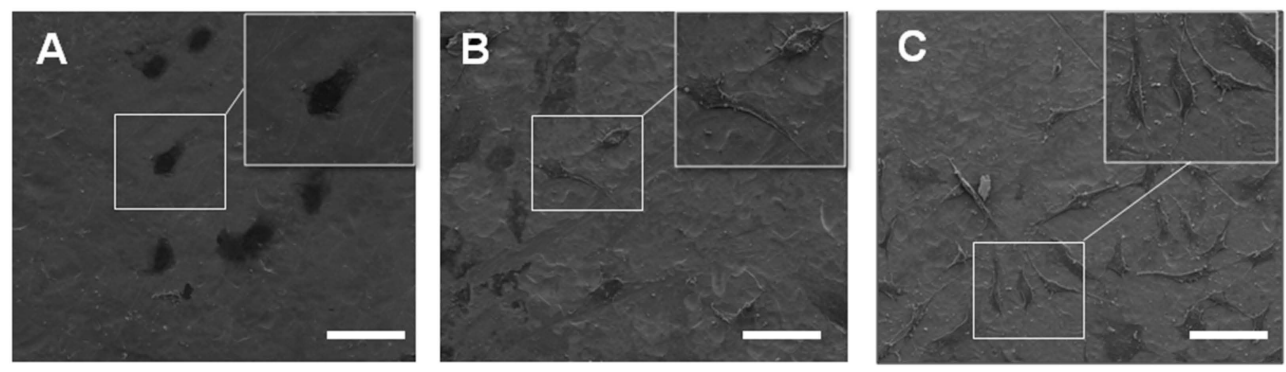

Figure 3. The morphology of MC3T3-E1 cells cultured on $\mathrm{Ti}(\mathbf{A})$; $\mathrm{TiO}_{2}-\mathrm{NTs}$ (B); and $\mathrm{Si}-\mathrm{TiO}_{2}-\mathrm{NTs}_{\text {(C) }}$ for $24 \mathrm{~h}$ as observed using SEM. Scale bars, $100 \mu \mathrm{m}$.
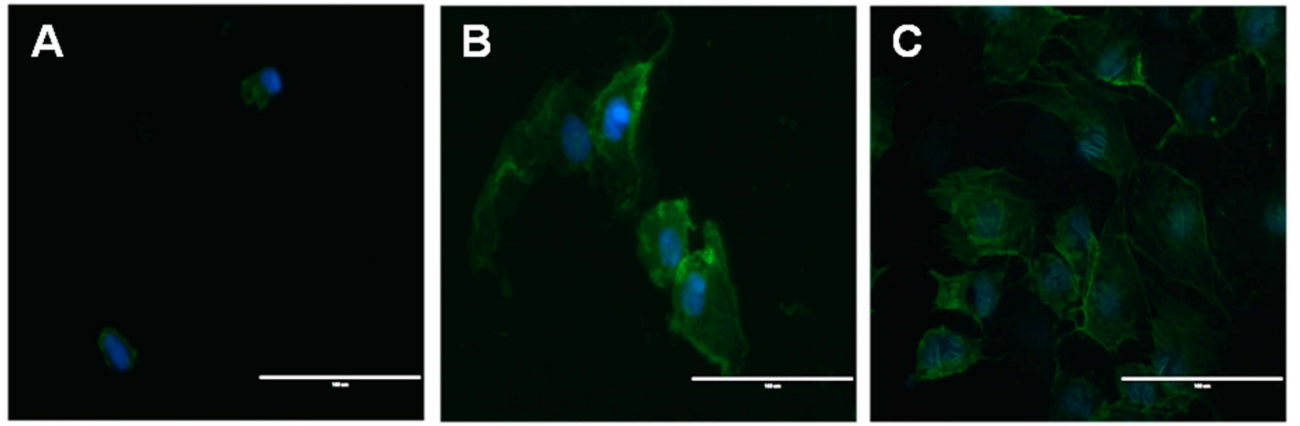

Figure 4. The immunofluorescence images of MC3T3-E1 cells that were stained with DAPI (blue) for nuclei and FITC-labeled phalloidin (green) for actin filaments after being cultured on (A); $\mathrm{TiO}_{2}-\mathrm{NTs}$ (B); and $\mathrm{Si}-\mathrm{TiO}_{2}-\mathrm{NTs}(\mathbf{C})$ for $12 \mathrm{~h}$. Scale bars, $100 \mu \mathrm{m}$. 
The proliferation of MC3T3-E1 cells cultured on $\mathrm{Ti}, \mathrm{TiO}_{2}-\mathrm{NT}$ and $\mathrm{Si}-\mathrm{TiO}_{2}-\mathrm{NT}$ substrates was measured via MTS assays (Figure 5). The number of cells on Ti substrates was obviously less than those on $\mathrm{TiO}_{2}-\mathrm{NT}$ and $\mathrm{Si}-\mathrm{TiO}_{2}-\mathrm{NT}$ groups $(p<0.01)$. There appeared to be no statistically significant difference between the proliferation rates of cells on $\mathrm{Si}-\mathrm{TiO}_{2}-\mathrm{NT}$ substrates and those on $\mathrm{TiO}_{2}-\mathrm{NTs}$.

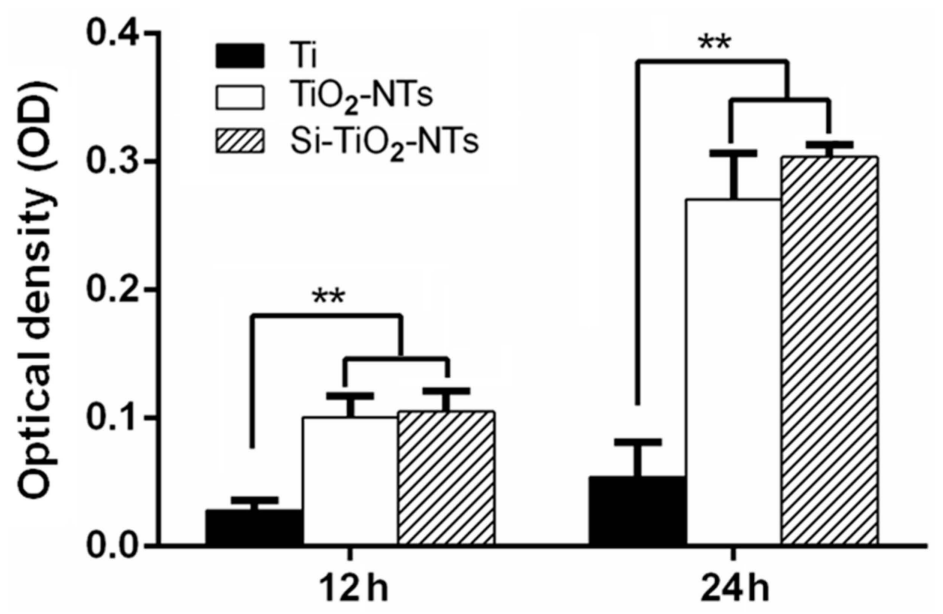

Figure 5. Proliferation of $\mathrm{MC} 3 \mathrm{~T} 3-\mathrm{E} 1$ cells on $\mathrm{Ti}, \mathrm{TiO}_{2}-\mathrm{NT}$ and $\mathrm{Si}-\mathrm{TiO}_{2}-\mathrm{NT}$ substrates. ${ }^{* *}, p<0.01$.

\subsection{Osteogenic Gene Expression and Mineralization}

The expression of typical osteogenic differentiation-associated genes, including Col-I, ALP, Runx2, OCN, and OPN, in MC3T3-E1 cells was determined using real time PCR (Figure 6). Clearly, the expression of all above genes in the cells cultured on $\mathrm{Si}-\mathrm{TiO}_{2}-\mathrm{NTs}$ for 7 days was significantly stronger than that of cells on $\mathrm{Ti}$ and $\mathrm{TiO}_{2}-\mathrm{NT}$ substrates $(p<0.01)$. Therefore, the osteogenic activity of cells was improved when they were cultured on $\mathrm{Si}-\mathrm{TiO}_{2}-\mathrm{NTs}$ compared to both $\mathrm{Ti}$ and $\mathrm{TiO}_{2}-\mathrm{NTs}$.
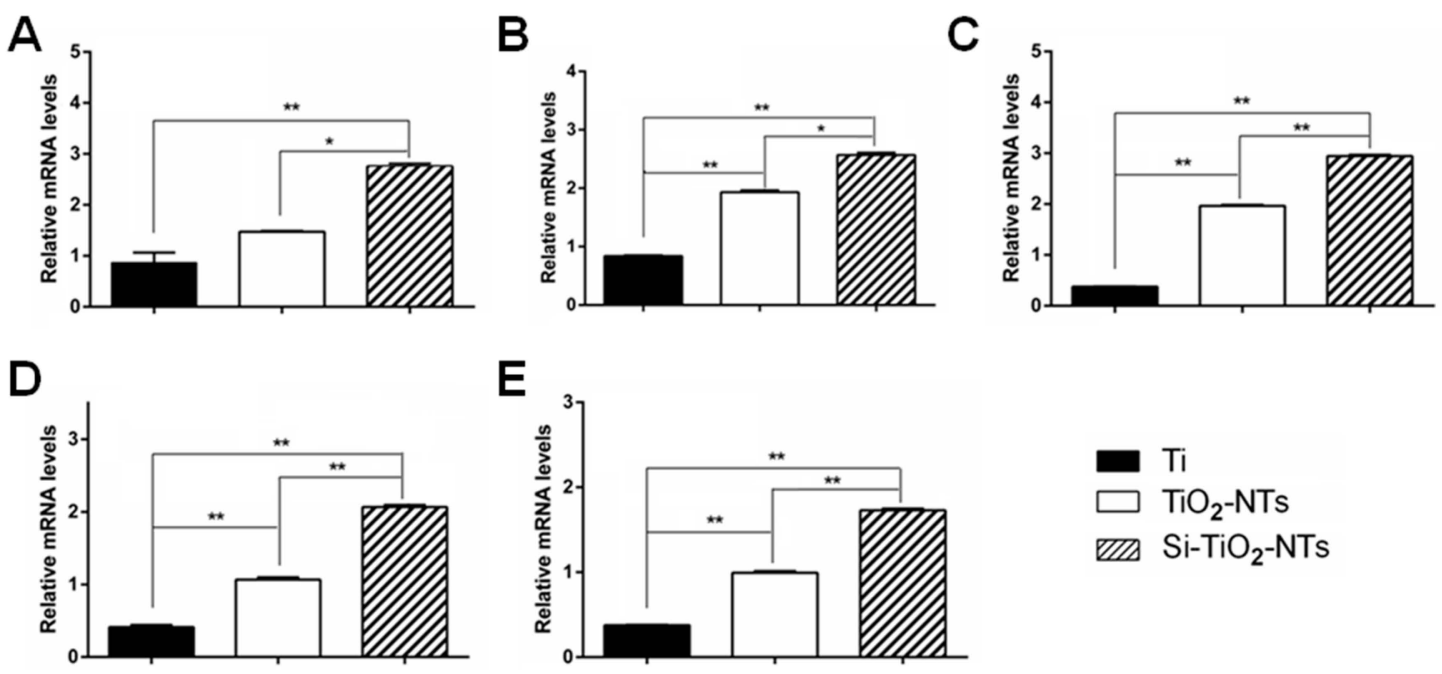

Figure 6. The expression of osteogenic differentiation related genes in MC3T3-E1 cells cultured on $\mathrm{Ti}, \mathrm{TiO}_{2}-\mathrm{NT}$, and $\mathrm{Si}-\mathrm{TiO}_{2}-\mathrm{NT}$ substrates for seven days. (A) Col-I; (B) ALP; (C) Runx2; (D) OCN; and (E) OPN. ${ }^{*}, p<0.05 ;{ }^{* *}, p<0.01$.

Figure 7 shows the extent of calcium deposition of MC3T3-E1 cells after two weeks of culture. The amount of mineralization, shown by the mineral nodule formation, by the cells cultured on $\mathrm{Si}_{-} \mathrm{TiO}_{2}-\mathrm{NT}$ substrates was markedly higher compared to those on $\mathrm{Ti}$ and $\mathrm{TiO}_{2}-\mathrm{NT}$ substrates. In addition, the cells cultured on $\mathrm{TiO}_{2}-\mathrm{NT}$ substrates also had more calcium deposition than those on Ti substrates $(p<0.05)$. 


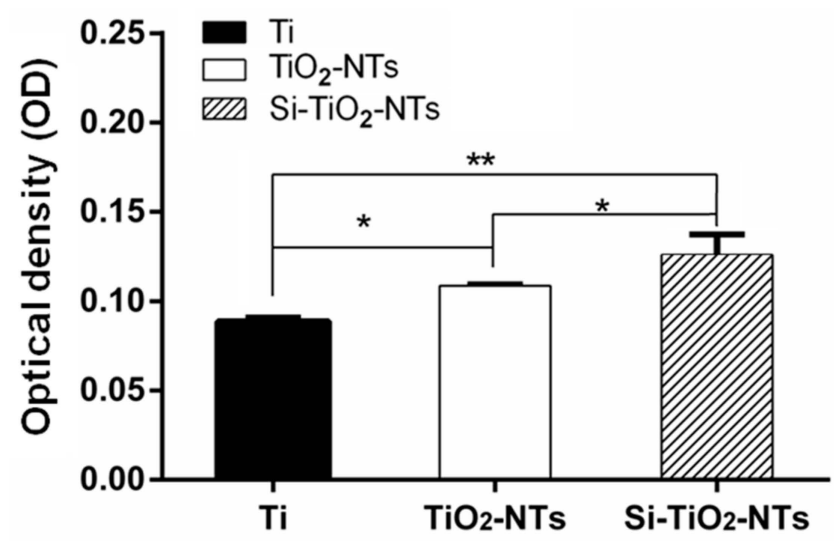

Figure 7. The extent of mineralization of MC3T3-E1 cells after 14 days of culture on $\mathrm{Ti}_{1} \mathrm{TiO}_{2}-\mathrm{NT}$, and $\mathrm{Si}-\mathrm{TiO}_{2}-\mathrm{NT}$ substrates. The samples were fixed and stained with alizarin red, which was then dissolved using $0.5 \mathrm{~mol} / \mathrm{L} \mathrm{HCl}$ and $5 \%$ SDS. The optical density of the solutions was measured as an indication of mineralization level. ${ }^{*}, p<0.05 ;{ }^{* *}, p<0.01$.

\subsection{Mechanical Tests}

In order to check the integration between Ti-based substrates and bone tissue, pull-out tests were performed using Ti screws and Ti screws treated with $\mathrm{TiO}_{2}-\mathrm{NTs}$ or $\mathrm{Si}-\mathrm{TiO}_{2}-\mathrm{NTs}$. The screws were implanted in the femur of rats for two weeks prior to pull-out tests. The peak pull-out force indicates the strength of screw fixation which is affected by the implant-bone integration. Apparently, both $\mathrm{Si}-\mathrm{TiO}_{2}-\mathrm{NT}$ and $\mathrm{TiO}_{2}-\mathrm{NT}$ screws resulted in stronger implant fixation than Ti screws (Figure 8). With the use of $\mathrm{Si}-\mathrm{TiO}_{2}-\mathrm{NT}$ screws, the peak pull-out force was increased by $18 \%$ and $54 \%$ compared to the use of $\mathrm{TiO}_{2}-\mathrm{NT}$ and Ti screws, respectively $(p<0.05)$.

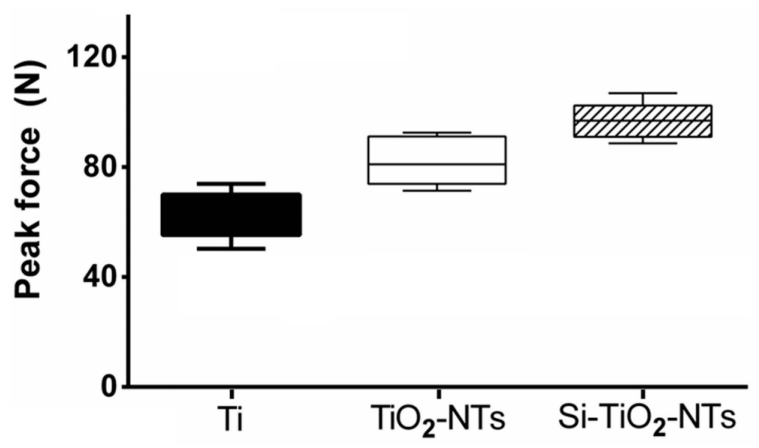

Figure 8. The peak pull-out forces upon removal of $\mathrm{Ti}, \mathrm{TiO}_{2}-\mathrm{NT}$, and $\mathrm{Si}-\mathrm{TiO}_{2}-\mathrm{NT}$ screws after two weeks of implantation in rat femur $(p<0.05)$.

\section{Discussion}

Insufficient osseointegration is the major cause of orthopaedic implant loosening which leads to the failure of implants after total joint replacement or spinal fusion surgeries [3,4]. The surface chemistry and topography of implants are the most critical features that ultimately determine their ability to integrate with the surrounding bone tissue [34]. $\mathrm{TiO}_{2}$ nanotubes have been shown to enhance cell adhesion, proliferation, and differentiation [35-37]. Meanwhile, Si-substituted bioceramics promote osteogenesis and bone formation $[27,30,38]$. Therefore, it is anticipated that $\mathrm{Si}$-doped $\mathrm{TiO}_{2}$ nanotubes may further enhance the growth activity and osteogenic potential of osteoblastic cells as a result of the synergistic effect of nanotubular microstructure and Si chemistry.

As expected, MC3T3-E1 cells showed more spread morphology and extended more filopodia when cultured on both $\mathrm{Si}-\mathrm{TiO}_{2}-\mathrm{NT}$ and $\mathrm{TiO}_{2}-\mathrm{NT}$ substrates compared to those on $\mathrm{Ti}$ surfaces 
(Figures 3 and 4). This is in accordance with a number of previous studies in which both surface micro-/nano-topography and Si doping were found to markedly affect cellular behaviors $[32,39,40]$. All substrates did not show any cytotoxicity. However, cells apparently proliferated faster on $\mathrm{Si}-\mathrm{TiO}_{2}-\mathrm{NT}$ and $\mathrm{TiO}_{2}-\mathrm{NT}$ substrates compared to $\mathrm{Ti}$ (Figure 5). It is likely that the size of $\mathrm{TiO}_{2}$ nanotubes (70-100 nm) favored integrin clustering and focal contact formation of cells, thus providing adequate anchoring sites for the cells [41]. Further doping with Si did not bring in any negative effect.

Osseointegration is a late stage of the evolution of implant fixation, characterized by the establishment of bone-implant contact and peri-implant bone development following bone matrix mineralization [42]. As seen, the expression of typical osteogenic genes (Col-I, ALP, Runx2, OCN and OPN) was markedly up-regulated in MC3T3-E1 cells cultured on $\mathrm{Si}-\mathrm{TiO}_{2}-\mathrm{NT}$ substrates compared to those on $\mathrm{Ti}$ and $\mathrm{TiO}_{2}-\mathrm{NTs}$ (Figure 6). Among them, Col-I is the major component which makes up over $90 \%$ of the organic bone matrix, ALP represents a specific subset of markers of osteoblast phenotype, Runx 2 is the main transcription factor required for the osteoblast lineage commitment of multipotent mesenchymal cells, yet OCN and OPN indicate the onset of mineralization $[43,44]$. In addition, $\mathrm{Si}-\mathrm{TiO}_{2}-\mathrm{NT}$ substrates promoted the formation of minerals better than $\mathrm{TiO}_{2}-\mathrm{NT}$ and $\mathrm{Ti}$ substrates (Figure 7). Therefore, although there was no marked difference between the cell proliferation on $\mathrm{Si}-\mathrm{TiO}_{2}-\mathrm{NT}$ and $\mathrm{TiO}_{2}-\mathrm{NT}$ substrates, the osteogenic activity of cells was markedly improved when they were cultured on $\mathrm{Si}-\mathrm{TiO}_{2}-\mathrm{NT}$ compared to both $\mathrm{TiO}_{2}-\mathrm{NT}$ and $\mathrm{Ti}$ substrates. The fact that $\mathrm{Si}$ doping affected the differentiation of cells, but not their proliferation, on $\mathrm{TiO}_{2}-\mathrm{NT}$ treated surfaces slightly differs from our previous finding, in which Si-doped $\mathrm{TiO}_{2}$ films appeared to favor both osteoblastic proliferation and differentiation [32]. This might be the result of the topographical difference (rough $\mathrm{TiO}_{2}$ nanotubes versus relatively smooth $\mathrm{TiO}_{2}$ film surface).

The enhanced osteogenic capacity of $\mathrm{Si}_{-}-\mathrm{TiO}_{2}-\mathrm{NT}$ substrates is a very important attribute for in vivo implantation as it allows more new bone formation on the implant surface and therefore strengthens the interlocking between implant and bone tissue. Indeed, we found significantly increased implant fixation strength with $\mathrm{Si}-\mathrm{TiO}_{2}-\mathrm{NT}$ implants after an implantation period as short as two weeks (Figure 8). The peak pull-out force of $\mathrm{Si}-\mathrm{TiO}_{2}-\mathrm{NT}$ implants was not only substantially greater than that of $\mathrm{Ti}$ implants ( $54 \%$ higher), but also markedly larger than that with $\mathrm{TiO}_{2}-\mathrm{NTs}(18 \%$ higher). Such biomechanical test results correlate well with the gene expression and mineralization results (Figures 6 and 7), implying that the increased matrix deposition and mineralization around $\mathrm{Si}^{-\mathrm{TiO}_{2}-\mathrm{NT}}$ screws significantly enhanced the osseointegration of implants.

\section{Materials and Methods}

\subsection{Materials}

$\mathrm{Ti}(99.6 \%$ purity) in the form of discs with diameter of 5.8, 13 and $31 \mathrm{~mm}$, respectively, and thickness of $1 \mathrm{~mm}$ were used in this study. For in vivo experiments, pure Ti screws, which were $10 \mathrm{~mm}$ long and had outer thread diameter of $2.0 \mathrm{~mm}$ and inner thread diameter of $1.7 \mathrm{~mm}$, were used. The material was supplied by Tianjin Zhengtian Medical Device Company (Tianjin, China).

\subsection{Fabrication of $\mathrm{TiO}_{2}$ Nanotube-Coated Ti Substrates}

Pure titanium screws and discs were ultrasonically cleaned using ethanol and deionized water consequently before being treated using $5 \mathrm{wt} \%$ oxalic acid solution at $100{ }^{\circ} \mathrm{C}$ for $2 \mathrm{~h}$ [45]. Following that, the pretreated specimens were anodized at a constant direct current (DC, 20 V) for $30 \mathrm{~min}$ in an electrolyte composed of $1.0 \mathrm{wt} \%$ hydrofluoric acid. After the anodizing oxidation, the specimens were rinsed with distilled water and air-dried. The morphology of $\mathrm{TiO}_{2}$ nanotubes on the surface of specimens was characterized by field emission scanning electron microscopy (SEM) (S-4800, Hitachi, Tokyo, Japan). 


\subsection{Si Plasma Immersion Ion Implantation (Si-PIII)}

Si was implanted into the $\mathrm{TiO}_{2}$ nanotubes using a filtered cathodic arc plasma source. In brief, a curved magnetic duct was inserted between the plasma source and main chamber for removing the macro-particles generated by the cathodic arc. The cathode rod, $10 \mathrm{~mm}$ in diameter, was made of $99.99 \%$ pure metallic $\mathrm{Si}$. The discharge of $\mathrm{Si}$ ions was regulated by the main arc current between the cathode and anode. By applying a pulsed high voltage to the $\mathrm{TiO}_{2}$ nanotubes samples, $\mathrm{Si}$ ions were implanted. The ion implantation time was $0.5,1,1.5 \mathrm{~h}$ and the pressure was $2.5 \times 10^{-3} \mathrm{~Pa}$. During Si-PIII, the main arc current and the pulsed high voltage that was applied to the target were synchronized at a frequency of $6 \mathrm{~Hz}$. The pulse duration of high voltage was set at $450 \mathrm{~ms}$. During Si-PIII, the sample stage was actively cooled by circulating water to keep the sample temperature at $25^{\circ} \mathrm{C}$.

\subsection{Surface Characterizations}

The morphology of sample surfaces was examined using SEM (S-3400, Hitachi, Tokyo, Japan). The surface chemistry and elemental depth profiles were determined using XPS (PHI 5802, Physical Electronics, London, UK). The Si, C, O, and Ti profiles were acquired by XPS in conjunction with argon ion bombardment at a sputtering rate of about $4 \mathrm{~nm} / \mathrm{min}$.

\subsection{Cell Culture}

MC3T3-E1 mouse preosteoblasts (CRL-2594, subclone 14, ATCC) were cultured in $\alpha$ - mininum essential medium ( $\alpha$-MEM, Gibco, Grand Island, NY, USA) supplemented with $10 \%$ fetal bovine serum (Gibco) and $1 \%$ penicillin/streptomycin at $37{ }^{\circ} \mathrm{C}$ in a $5 \% \mathrm{CO}_{2}$ environment. Cells were seeded onto different experimental substrates. The plates with dimensions $5.8 \mathrm{~mm}$ were placed on 96 -well polystyrene plates. The cells were seeded onto the specimen substrate at an initial density of $1 \times 10^{4}$ cells $/$ well. The $13 \mathrm{~mm}$ plates were placed on 24-well polystyrene plates and the concentration was $3 \times 10^{4} \mathrm{cells} /$ well. The $31 \mathrm{~mm}$ plates were placed on 6-well polystyrene plates and the concentration was $3 \times 10^{5}$ cells/well. In the osteogenic differentiation assay, after the cells were cultured for $24 \mathrm{~h}$, the medium was further supplemented with $\beta$-glycerol phosphate $(10 \mathrm{mM})$, ascorbic acid $(50 \mu \mathrm{g} / \mathrm{mL})$, and dexamethasone $(10 \mathrm{nM})$ for osteogenic induction. The media were refreshed every 3 days.

\subsection{Cell Morphology}

The cells on surfaces with a diameter of $5.8 \mathrm{~mm}$ were cultured $24 \mathrm{~h}$. After washed with PBS, the samples were fixed using 2.5\% glutaraldehyde (Sigma, St. Louis, MO, USA) in PBS for $1 \mathrm{~h}$ and then rinsed three times with PBS for $10 \mathrm{~min}$. After that, the cells were dehydrated in a graded series of ethanol (30\%, 50\%, 70\%, 90\% and 100\%) for 30 min each and left in 100\% ethanol. The samples were dried using a Critical Point Dryer (CPD030, LEICA, Wetzlar, Germany) and sputter-coated with gold using an Ion Sputter (SC7620, Quorum Technologies, Lewes, UK). Finally, the morphology of cells was observed by SEM (Quanta 250, FEI, Hillsboro, OR, USA).

\subsection{Immunofluorescence of Cytoskeletal Actin}

After culturing for $24 \mathrm{~h}$, MC3T3-E1 cells were fixed using 4\% paraformaldehyde in PBS for $15 \mathrm{~min}$ at room temperature. The cells were then washed twice with PBS and permeabilized with Triton X-100. After that, they were incubated with FITC-labeled phalloidin $(5 \mu \mathrm{g} / \mathrm{mL}$ in PBS) containing $1 \% \mathrm{BSA}$ for $1 \mathrm{~h}$ at room temperature. Then, the cell nuclei were stained with DAPI. The cells were washed three times with PBS for 5 min each wash. Cell morphology and cytoskeletal arrangement were observed using an EVOS fluorescence microscope (AMG, Thornwood, NY, USA).

\subsection{MTS Assay}

Cell proliferation was evaluated using MTS assay. Samples with $5.8 \mathrm{~mm}$ in diameter were placed in a 96-well plate. The concentration was $1 \times 10^{4}$ cells/well. Cells were cultured for 12 and $24 \mathrm{~h}$, 
respectively, at $37{ }^{\circ} \mathrm{C}$ and $5 \% \mathrm{CO}_{2}$. At predetermined periods, samples were washed three times with PBS and transferred to a new 96-well polystyrene culture plate. After that, $100{ }^{\circ} \mathrm{C}$ culture medium and $20 \mu \mathrm{L}$ MTS reagent (Promega, Madison, WI, USA) were added to each well following the manufacturer's directions. After $2 \mathrm{~h}$ of incubation under $5 \% \mathrm{CO}_{2}$ atmosphere, the absorbance at a wavelength of $490 \mathrm{~nm}$ of each solution was measured using a 96-well plate reader.

\subsection{Mineralization Assay}

The degree of osteogenesis was evaluated by Alizarin Red S (Sigma) staining. After osteogenic induction for 2 weeks, three experimental surfaces with $13 \mathrm{~mm}$ in diameter were fixed in $75 \%$ ethanol for $1 \mathrm{~h}$. The cells were rinsed with distilled water and stained using $200 \mu \mathrm{L}$ of $40 \mathrm{mmol} / \mathrm{L}$ Alizarin red S ( $\mathrm{pH}$ 4.1) solution for $10 \mathrm{~min}$ at room temperature. Afterwards, the unbound stain was totally removed by rinsing with double-distilled water. Quantitative analysis of Alizarin Red S staining was performed through solubilization with $0.5 \mathrm{~mol} / \mathrm{L} \mathrm{HCl}$ and $5 \%$ sodium dodecyl sulphate (SDS) for $30 \mathrm{~min}$ at room temperature [46]. Then, $100 \mu \mathrm{L}$ of the solubilized stain was determined by the absorbance at $405 \mathrm{~nm}$ measured using a spectrophotometer (U-3010, Hitachi, Tokyo, Japan).

\subsection{Quantitative Real-Time Polymerase Chain Reaction ( $q R T-P C R$ )}

MC3T3-E1 cells were first seeded on three experimental specimens $31 \mathrm{~mm}$ in diameter in 6-well plates at the density of $3 \times 10^{5}$ cells/well. After culturing for $24 \mathrm{~h}, 10 \mathrm{mM} \beta$-glycerol phosphate, $50 \mu \mathrm{g} / \mathrm{mL}$ ascorbic acid, and $10 \mathrm{nM}$ dexamethasone were added for osteogenic induction. After culturing with cells for 7 days, the three experimental specimens were rinsed three times with PBS, and the total RNA of cells was extracted with Trizol (Sigma). One microgram of total RNA was reverse transcribed into cDNA using SuperScript III First-Strand Synthesis System (Invitrogen, Carlsbad, CA, USA) according to the manufacturer's protocols. qRT-PCR was performed to evaluate the expression of Col-I, Runx2, ALP, OCN, and OPN. All samples were analyzed in triplicates. Data analysis was carried out using the iQ5 Optical System Software Version 2.0 (BioRad, Berkeley, CA, USA). The relative expression level (fold change) was calculated by converting the logarithmic values into absolute values using $2^{-\Delta \Delta C t}$. GAPDH was used as the housekeeping gene. The primer sequences of the genes are shown in Table 1.

Table 1. The sequences of the oligonucleotide primers for quantitative real-time polymerase chain reaction (qRT-PCR) assays.

\begin{tabular}{cccc}
\hline Gene & Primers Sequence & $\begin{array}{c}\text { Amplicon } \\
\text { Size (bp) }\end{array}$ & $\begin{array}{c}\text { Accession } \\
\text { Number }\end{array}$ \\
\hline Col-I & $\begin{array}{c}\text { Forward: 5'-CCTGAGTCAGCAGATTGAGAACA-3' } \\
\text { Reverse: 5'-CCAGTACTCTCCGCTCTTCCA-3' }\end{array}$ & 114 & NM_007742 \\
\hline OC & $\begin{array}{c}\text { Forward: 5'-CGCTCTGTCTCTCTGACCTC-3' } \\
\text { Reverse: 5'-CACTACCTTATTGCCCTCCTG-3' }\end{array}$ & 91 & NM_001037939 \\
\hline OPN & $\begin{array}{c}\text { Forward: 5'-CTTTCACTCCAATCGTCCCTAC-3' } \\
\text { Reverse: 5'-CAGAAACCTGGAAACTCCTAGAC-3' }\end{array}$ & 99 & NM_001204201 \\
\hline ALP & $\begin{array}{c}\text { Forward: 5'-GGGCATTGTGACTACCACTCG-3' } \\
\text { Reverse: 5'-CCTCTGGTGGCATCTCGTTAT-3' }\end{array}$ & 103 & NM_001287172 \\
\hline Runx2 & $\begin{array}{c}\text { Forward: 5'-GACACTGCCACCTCTGACTT-3' } \\
\text { Reverse: 5'-GATGAAATGCTTGGGAACTG-3' }\end{array}$ & 115 & NM_001145920 \\
\hline GAPDH & $\begin{array}{c}\text { Forward: 5'-CATCAAGAAGGTGGTGAAGC-3' } \\
\text { Reverse: 5'-CCTGTTGCTGTAGCCGTATT-3' }\end{array}$ & 198 & NM_001289726 \\
\hline
\end{tabular}

\subsection{Animal Surgeries and Mechanical Tests}

Nine male SD rats (weighing 260-280 g) supplied by Soochow University Animal Center were used for the animal tests. They were randomly divided into three groups according to the implants, 
i.e., pure titanium screws (Ti), titanium screws subjected to anodic oxidation treatment $\left(\mathrm{TiO}_{2}-\mathrm{NTs}\right)$, and titanium screws subjected to anodic oxidation and silicon plasma ion implantation treatments $\left(\mathrm{Si}-\mathrm{TiO}_{2}-\mathrm{NTs}\right)$. Systemic anesthesia was performed using ketamine and xylazine at 80-100 and $10-20 \mathrm{mg} / \mathrm{kg}$, respectively. In addition, local anesthesia was also performed at the surgery area using $2 \%$ lidocaine solution containing epinephrine $(1: 100,000)$. The hair of surgical site was shaved and sterilized with betadine scrubs. Flat surfaces of the distal femurs were selected for implant placement. The screws were implanted from the outside to the inside in the horizontal direction. Each rat received one implant in each femur. After 2 weeks, the experimental animals were sacrificed by an excessive intraperitoneal dose of sodium pentobarbital. Pull-out tests were performed for all implants (6 implants per group) in the femur. The screws were tested for pull-out strength using a materials testing system (HY-1080, Shanghai, China) at a test speed of $1 \mathrm{~mm} / \mathrm{s}$. The maximal force was considered as the pull-out force. All surgeries were performed according to the animal surgery protocol approved by the Institutional Animal Care and Use Committee (IACUC) of Soochow University. (Approval Date: 3 March 2014) All measurements were performed while the investigators were blinded for treatment.

\subsection{Statistical Analysis}

Each experiment was performed three times and the results were showed as mean \pm standard deviation. All data were analyzed using SPSS 13 software, with $p<0.05$ being considered statistically significant. The graphs show averages \pm standard error bars and the significance between groups is marked on the graphs.

\section{Conclusions}

In this study, $\mathrm{Ti}$ substrates that were decorated with $\mathrm{TiO}_{2}$ nanotubes at the surface and further doped with $\mathrm{Si}$ using plasma immersion ion implantation technology have been prepared. It was found that $\mathrm{TiO}_{2}-\mathrm{NT}$ and $\mathrm{Si}-\mathrm{TiO}_{2}-\mathrm{NT}$ substrates similarly promoted the adhesion and proliferation of pre-osteoblastic MC3T3-E1 cells compared to Ti alone. However, the osteogenic activities of cells, including the expression of genes associated with osteogenic differentiation and the matrix mineral deposition, were markedly enhanced on $\mathrm{Si}-\mathrm{TiO}_{2}-\mathrm{NT}$ substrates compared to $\mathrm{TiO}_{2}-\mathrm{NTs}$. After two weeks of implantation in rat femur, the pull-out tests showed that the fixation strength of $\mathrm{Si}-\mathrm{TiO}_{2}-\mathrm{NT}$ implants was $18 \%$ and $54 \%$ higher compared to $\mathrm{TiO}_{2}-\mathrm{NT}$ and $\mathrm{Ti}$ implants, respectively. Therefore, the synergetic effect of surface chemistry and nanostructured topography may predict substantially enhanced osteogenic potential of Ti substrates and improved bone-Ti integration, which is critical toward optimal orthopedic implants. Further studies will explore the specific mechanisms by investigating the effect of $\mathrm{Si}$ concentration at implant surface as well as comparative analysis of protein adsorption and biomolecule interactions on $\mathrm{Si}-\mathrm{TiO}_{2}-\mathrm{NT}$ and $\mathrm{TiO}_{2}-\mathrm{NT}$ surfaces.

Acknowledgments: The study was supported by the National Natural Science Foundation of China (81271959, 51401234, 81472060, and 81471790), Innovation Fund of SICCAS (Y46ZC3130G), Jiangsu Provincial Special Program of Medical Science (BL2012004), Jiangsu Provincial Clinical Orthopedic Center, and the Priority Academic Program Development (PAPD) of Jiangsu Higher Education Institutions.

Author Contributions: Xuanyong Liu, Junying Sun and Bin Li conceived and designed the experiments; Xijiang Zhao, Tao Wang and Shi Qian performed the experiments; Xijiang Zhao and Shi Qian analyzed the data; Xijiang Zhao and Bin Li wrote the paper.

Conflicts of Interest: The authors declare no conflict of interest.

\section{Abbreviations}

$\mathrm{Ti}$

$\mathrm{Si}$

$\mathrm{TiO}_{2}$

PIII
Titanium

Silicon

Titanium dioxide

Plasma immersion ion implantation 


$\begin{array}{ll}\text { THA } & \text { Total hip arthroplasty } \\ \text { MSCs } & \text { Mesenchymal stem cells } \\ \alpha \text {-TCP } & \alpha \text {-Tri-calcium phosphate } \\ \text { SEM } & \text { Scanning electron microscopy } \\ \text { XPS } & \text { X-ray photoelectron spectroscopy } \\ \alpha \text {-MEM } & \alpha \text {-Mininum essential medium } \\ \text { SDS } & \text { Sodium dodecyl sulphate } \\ \text { IACUC } & \text { Institutional Animal Care and Use Committee }\end{array}$

\section{References}

1. Linder, L.; Carlsson, A.; Marsal, L.; Bjursten, L.M.; Branemark, P.I. Clinical aspects of osseointegration in joint replacement. A histological study of titanium implants. J. Bone Jt. Surg. Br. 1988, 70, 550-555.

2. Rao, P.J.; Pelletier, M.H.; Walsh, W.R.; Mobbs, R.J. Spine interbody implants: Material selection and modification, functionalization and bioactivation of surfaces to improve osseointegration. Orthop. Surg. 2014, 6, 81-89. [CrossRef] [PubMed]

3. Hong, X.; Wu, X.T.; Zhuang, S.Y.; Bao, J.P.; Shi, R. New cage for posterior minimally invasive lumbar interbody fusion: A Study in vitro and in vivo. Orthop. Surg. 2014, 6, 47-53. [CrossRef] [PubMed]

4. Minagar, S.; Li, Y.; Berndt, C.C.; Wen, C. The influence of titania-zirconia-zirconium titanate nanotube characteristics on osteoblast cell adhesion. Acta Biomater. 2015, 12, 281-289. [CrossRef] [PubMed]

5. Schairer, W.W.; Sing, D.C.; Vail, T.P.; Bozic, K.J. Causes and frequency of unplanned hospital readmission after total hip arthroplasty. Clin. Orthop. Relat. Res. 2014, 472, 464-470. [CrossRef] [PubMed]

6. Liu, F.; Li, B.; Sun, J.Y.; Li, H.W.; Wang, B.; Zhang, S.L. Proliferation and differentiation of osteoblastic cells on titanium modified by ammonia plasma immersion ion implantation. Appl. Surf. Sci. 2012, 258, 4322-4327. [CrossRef]

7. Lou, W.; Dong, Y.; Zhang, H.; Jin, Y.; Hu, X.; Ma, J.; Liu, J.; Wu, G. Preparation and characterization of lanthanum-incorporated hydroxyapatite coatings on titanium substrates. Int. J. Mol. Sci. 2015, 16, 21070-21086. [CrossRef] [PubMed]

8. Lampin, M.; Warocquier, C.; Legris, C.; Degrange, M.; Sigot-Luizard, M.F. Correlation between substratum roughness and wettability, cell adhesion, and cell migration. J. Biomed. Mater. Res. 1997, 36, 99-108. [CrossRef]

9. Deligianni, D.D.; Katsala, N.D.; Koutsoukos, P.G.; Missirlis, Y.F. Effect of surface roughness of hydroxyapatite on human bone marrow cell adhesion, proliferation, differentiation and detachment strength. Biomaterials 2001, 22, 87-96. [CrossRef]

10. Sista, S.; Wen, C.; Hodgson, P.D.; Pande, G. The influence of surface energy of titanium-zirconium alloy on osteoblast cell functions in vitro. J. Biomed. Mater. Res. A 2011, 97, 27-36. [CrossRef] [PubMed]

11. Matena, J.; Petersen, S.; Gieseke, M.; Kampmann, A.; Teske, M.; Beyerbach, M.; Murua Escobar, H.; Haferkamp, H.; Gellrich, N.C.; Nolte, I. Slm produced porous titanium implant improvements for enhanced vascularization and osteoblast seeding. Int. J. Mol. Sci. 2015, 16, 7478-7492. [CrossRef] [PubMed]

12. Lin, L.; Wang, H.; Ni, M.; Rui, Y.; Cheng, T.; Cheng, C.; Pan, X.; Li, G.; Lin, C. Enhanced osteointegration of medical titanium implant with surface modifications in micro/nanoscale structures. J. Orthop. Trans. 2014, 2, 35-42. [CrossRef]

13. Dalby, M.J. Nanostructured surfaces: Cell engineering and cell biology. Nanomedicine 2009, 4, $247-248$. [CrossRef] [PubMed]

14. Gong, T.; Xie, J.; Liao, J.; Zhang, T.; Lin, S.; Lin, Y. Nanomaterials and bone regeneration. Bone Res. 2015, 3, 15029. [CrossRef] [PubMed]

15. Brammer, K.S.; Frandsen, C.J.; Jin, S. $\mathrm{TiO}_{2}$ nanotubes for bone regeneration. Trends Biotechnol. 2012, 30, 315-322. [CrossRef] [PubMed]

16. Bjursten, L.M.; Rasmusson, L.; Oh, S.; Smith, G.C.; Brammer, K.S.; Jin, S. Titanium dioxide nanotubes enhance bone bonding in vivo. J. Biomed. Mater. Res. A 2010, 92, 1218-1224. [PubMed]

17. Oh, S.; Daraio, C.; Chen, L.H.; Pisanic, T.R.; Finones, R.R.; Jin, S. Significantly accelerated osteoblast cell growth on aligned $\mathrm{TiO}_{2}$ nanotubes. J. Biomed. Mater. Res. A 2006, 78, 97-103. [CrossRef] [PubMed] 
18. Popat, K.C.; Leoni, L.; Grimes, C.A.; Desai, T.A. Influence of engineered titania nanotubular surfaces on bone cells. Biomaterials 2007, 28, 3188-3197. [CrossRef] [PubMed]

19. Yao, C.; Slamovich, E.B.; Webster, T.J. Enhanced osteoblast functions on anodized titanium with nanotube-like structures. J. Biomed. Mater. Res. A 2008, 85, 157-166. [CrossRef] [PubMed]

20. Brammer, K.S.; Choi, C.; Frandsen, C.J.; Oh, S.; Johnston, G.; Jin, S. Comparative cell behavior on carbon-coated $\mathrm{TiO}_{2}$ nanotube surfaces for osteoblasts vs. Osteo-progenitor cells. Acta Biomater. 2011, 7, 2697-2703. [CrossRef] [PubMed]

21. Frandsen, C.J.; Brammer, K.S.; Noh, K.; Johnston, G.; Jin, S. Tantalum coating on $\mathrm{TiO}_{2}$ nanotubes induces superior rate of matrix mineralization and osteofunctionality in human osteoblasts. Mater. Sci. Eng. C 2014, 37, 332-341. [CrossRef] [PubMed]

22. Qiao, Y.; Zhang, W.; Tian, P.; Meng, F.; Zhu, H.; Jiang, X.; Liu, X.; Chu, P.K. Stimulation of bone growth following zinc incorporation into biomaterials. Biomaterials 2014, 35, 6882-6897. [CrossRef] [PubMed]

23. Wang, G.; Li, J.; Zhang, W.; Xu, L.; Pan, H.; Wen, J.; Wu, Q.; She, W.; Jiao, T.; Liu, X.; et al. Magnesium ion implantation on a micro/nanostructured titanium surface promotes its bioactivity and osteogenic differentiation function. Int. J. Nanomed. 2014, 9, 2387-2398.

24. Zhang, Z.; Sun, J.; Hu, H.; Wang, Q.; Liu, X. Osteoblast-like cell adhesion on porous silicon-incorporated $\mathrm{TiO}_{2}$ coating prepared by micro-arc oxidation. J. Biomed. Mater. Res. B 2011, 97, 224-234. [CrossRef] [PubMed]

25. Carlisle, E.M. Silicon: A possible factor in bone calcification. Science 1970, 167, 279-280. [CrossRef] [PubMed]

26. Botelho, C.M.; Brooks, R.A.; Spence, G.; McFarlane, I.; Lopes, M.A.; Best, S.M.; Santos, J.D.; Rushton, N.; Bonfield, W. Differentiation of mononuclear precursors into osteoclasts on the surface of si-substituted hydroxyapatite. J. Biomed. Mater. Res. A 2006, 78, 709-720. [CrossRef] [PubMed]

27. Botelho, C.M.; Brooks, R.A.; Best, S.M.; Lopes, M.A.; Santos, J.D.; Rushton, N.; Bonfield, W. Human osteoblast response to silicon-substituted hydroxyapatite. J. Biomed. Mater. Res. A 2006, 79, 723-730. [CrossRef] [PubMed]

28. Honda, M.; Kikushima, K.; Kawanobe, Y.; Konishi, T.; Mizumoto, M.; Aizawa, M. Enhanced early osteogenic differentiation by silicon-substituted hydroxyapatite ceramics fabricated via ultrasonic spray pyrolysis route. J. Mater. Sci. Mater. Med. 2012, 23, 2923-2932. [CrossRef] [PubMed]

29. Mate-Sanchez de Val, J.E.; Calvo-Guirado, J.L.; Delgado-Ruiz, R.A.; Ramirez-Fernandez, M.P.; Negri, B.; Abboud, M.; Martinez, I.M.; de Aza, P.N. Physical properties, mechanical behavior, and electron microscopy study of a new $\alpha$-TCP block graft with silicon in an animal model. J. Biomed. Mater. Res. A 2012, 100, 3446-3454. [CrossRef] [PubMed]

30. Camiré, C.L.; Jegou Saint-Jean, S.; Mochales, C.; Nevsten, P.; Wang, J.S.; Lidgren, L.; McCarthy, I.; Ginebra, M.P. Material characterization and in vivo behavior of silicon substituted $\alpha$-tricalcium phosphate cement. J. Biomed. Mater. Res. B Appl. Biomater. 2006, 76, 424-431. [CrossRef] [PubMed]

31. Schwarz, K.; Milne, D.B. Growth-promoting effects of silicon in rats. Nature 1972, 239, 333-334. [CrossRef] [PubMed]

32. Wang, B.; Sun, J.; Qian, S.; Liu, X.; Zhang, S.; Liu, F.; Dong, S.; Zha, G. Proliferation and differentiation of osteoblastic cells on silicon-doped $\mathrm{TiO}_{2}$ film deposited by cathodic arc. Biomed. Pharmacother. 2012, 66, 633-641. [CrossRef] [PubMed]

33. Wang, B.; Sun, J.Y.; Qian, S.; Liu, X.Y.; Zhang, S.L.; Dong, S.J.; Zha, G.C. Adhesion of osteoblast-like cell on silicon-doped $\mathrm{TiO}_{2}$ film prepared by cathodic arc deposition. Biotechnol. Lett. 2013, 35, 975-982. [CrossRef] [PubMed]

34. Kieswetter, K.; Schwartz, Z.; Dean, D.D.; Boyan, B.D. The role of implant surface characteristics in the healing of bone. Crit. Rev. Oral Biol. Med. 1996, 7, 329-345. [CrossRef] [PubMed]

35. Park, J.; Bauer, S.; von der Mark, K.; Schmuki, P. Nanosize and vitality: $\mathrm{TiO}_{2}$ nanotube diameter directs cell fate. Nano. Lett. 2007, 7, 1686-1691. [CrossRef] [PubMed]

36. Park, J.; Bauer, S.; Schlegel, K.A.; Neukam, F.W.; von der Mark, K.; Schmuki, P. TiO 2 nanotube surfaces: $15 \mathrm{~nm}$-An optimal length scale of surface topography for cell adhesion and differentiation. Small 2009, 5, 666-671. [CrossRef] [PubMed]

37. Park, J.; Bauer, S.; Schmuki, P.; von der Mark, K. Narrow window in nanoscale dependent activation of endothelial cell growth and differentiation on $\mathrm{TiO}_{2}$ nanotube surfaces. Nano Lett. 2009, 9, 3157-3164. [CrossRef] [PubMed]

38. Langstaff, S.; Sayer, M.; Smith, T.J.; Pugh, S.M. Resorbable bioceramics based on stabilized calcium phosphates. Part II: Evaluation of biological response. Biomaterials 2001, 22, 135-150. [CrossRef] 
39. Frandsen, C.J.; Noh, K.; Brammer, K.S.; Johnston, G.; Jin, S. Hybrid micro/nano-topography of a $\mathrm{TiO}_{2}$ nanotube-coated commercial zirconia femoral knee implant promotes bone cell adhesion in vitro. Mater. Sci. Eng. C Mater. Biol. Appl. 2013, 33, 2752-2756. [CrossRef] [PubMed]

40. Yu, W.Q.; Jiang, X.Q.; Zhang, F.Q.; Xu, L. The effect of anatase $\mathrm{TiO}_{2}$ nanotube layers on $\mathrm{MC} 3 \mathrm{~T} 3-\mathrm{E} 1$ preosteoblast adhesion, proliferation, and differentiation. J. Biomed. Mater. Res. A 2010, 94, 1012-1022. [CrossRef] [PubMed]

41. Brammer, K.S.; Oh, S.; Cobb, C.J.; Bjursten, L.M.; van der Heyde, H.; Jin, S. Improved bone-forming functionality on diameter-controlled $\mathrm{TiO}_{2}$ nanotube surface. Acta Biomater. 2009, 5, 3215-3223. [CrossRef] [PubMed]

42. Khan, M.R.; Donos, N.; Salih, V.; Brett, P.M. The enhanced modulation of key bone matrix components by modified titanium implant surfaces. Bone 2012, 50, 1-8. [CrossRef] [PubMed]

43. Christenson, R.H. Biochemical markers of bone metabolism: An overview. Clin. Biochem. 1997, 30, 573-593. [CrossRef]

44. Phimphilai, M.; Zhao, Z.; Boules, H.; Roca, H.; Franceschi, R.T. Bmp signaling is required for runx2-dependent induction of the osteoblast phenotype. J. Bone Miner. Res. 2006, 21, 637-646. [CrossRef] [PubMed]

45. Zhang, W.; Jin, Y.; Qian, S.; Li, J.; Chang, Q.; Ye, D.; Pan, H.; Zhang, M.; Cao, H.; Liu, X.; et al. Vacuum extraction enhances rhPDGF-BB immobilization on nanotubes to improve implant osseointegration in ovariectomized rats. Nanomedicine 2014, 10, 1809-1818. [CrossRef] [PubMed]

46. Yamamoto, O.; Alvarez, K.; Kashiwaya, Y.; Fukuda, M. Surface characterization and biological response of carbon-coated oxygen-diffused titanium having different topographical surfaces. J. Mater. Sci. Mater. Med. 2011, 22, 977-987. [CrossRef] [PubMed]

(C) 2016 by the authors; licensee MDPI, Basel, Switzerland. This article is an open access article distributed under the terms and conditions of the Creative Commons by Attribution (CC-BY) license (http://creativecommons.org/licenses/by/4.0/). 